Short Note

\title{
Comparison of forest cover mapping results of two successive forest resource assessments of Nepal
}

\author{
S. Khanal ${ }^{1 *}$, B. S. Poudel ${ }^{1}$, P. Mathema ${ }^{1}$, Y. P. Pokharel ${ }^{1}$ and D. K. Kharal ${ }^{1}$
}

I Nepal, the first national-level forest inventory was carried out in the 1960s (FRS, 1967). Since then, several forms of forest resource assessment activities have been carried out in different periods, each different in terms of purpose, scale, scope, design and technology used. Six nationallevel forest cover assessments were carried out in the last four decades (DFRS, 1999; 2015).

Results of nation-wide forest resource assessment (2010-2014) of Nepal were recently published (DFRS, 2015). As per the assessment, Forest $\mathrm{t}^{\mathrm{a}}$ covers 5.96 million ha (40.36\%), Other Wooded Land ${ }^{\mathrm{b}}$ covers 0.65 million ha $(4.38 \%)$ and Other Land $^{\mathrm{c}}$ covers 8.16 million ha $(55.26 \%)$. Forest and OWL together comprise $44.74 \%$ of the total area of the country. The previous nation-wide forest resource assessment (NFI, 1994) was done in 1990s (DFRS, 1999). The forest area as estimated by NFI (1994) was $29 \%$ (4.27 million ha) and shrub $10.6 \%$, making a total of $39.6 \%$ of the geographical area of the country. Both of these nation-wide forest resource assessments were conducted by the Department of Forest Research and Survey, with support from the Government of Finland. One of the key interests after successive assessments is the change in forest parameters between the assessment periods. In this context, the forest area estimated by the recent FRA is more than that of the NFI of 1990s which may be attributed to three factors: (1) higher mapping resolution of FRA (ii) abandonment of agricultural land, which in turn changed to forested land, and (iii) the community forestry interventions (DFRS, 2015). However, given the methodological differences between NFI and

FRA, it is difficult to conclude that the forest area has increased between the two assessments.

This paper aims to briefly highlight the problems associated with comparison of results between the two assessments. One key issue is the difference in materials and methodologies used. With the development of science and technology, newer methods are being developed and are improving the accuracy of forest parameters estimation. The latest assessment applied a set of materials and methods more advanced than the previous one. The comparison of the results in terms of forest resource estimates is problematic due to differences in methods, materials, duration of assessments as well as validation approach used. One analogous example includes a recent global estimate of total tree number as 3.04 trillion which is more than seven times the previous estimate done in 2008 (Crowther et al., 2015). Certainly, this doesn't necessarily imply increase in tree number, but could be attributed to improvement in the methodology adopted.

The FRA of 2010s has some key differences as compared to the NFI of 1990s. All the sample plots measured in the recent FRA have georeferenced locations, and are set up as permanent sample plots (PSPs). Besides, the recent FRA is more comprehensive with a scope of reassessment. Furthermore, the recent FRA is a multi-source forest resource assessment, as it included additional variables (soil characteristics, soil carbon, litter and dead wood, stump and disturbance) in addition to tree parameters. Unlike the previous assessment, which excluded

\footnotetext{
Department of Forest Research and Survey, Babarmahal, Kathmandu, * E-mail: skhanal@dfrs.gov.np

a Forest is defined as an area of land at least 0.5 ha in area and a minimum width/length of $20 \mathrm{~m}$ with a tree crown cover of more than $10 \%$ and tree heights of $5 \mathrm{~m}$ at maturity;

b Other Wooded Land (OWL) includes: (i) the land not classified as forest spanning over more than 0.5 ha, having at least $20 \mathrm{~m}$ width and with $5-10 \%$ tree canopy cover, (ii) the land with less than $5 \%$ tree canopy cover, but the combined cover of more than 10\% shrubs, bushes and trees; and (iii) the areas of shrubs and bushes where no trees are present; and

Other Land (OL) refers to all other land areas that are not classified as Forest or Other Wooded Land
} 
the protected areas (PAs), this assessment had sample plots across the entire country including the PAs.

The key differences between the two national forest assessments of 1990s and 2010s can be summarized under materials, methods, duration of assessment and verification approach (Table 1). Scale of the base data used for mapping is one important determinant of the comparability of output products. Since the resolution of the image (Landsat TM) used in the 1990s for a portion of Nepal is $30 \mathrm{~m}$, the smaller forest patches could have been excluded from forest cover mapping. However, high-resolution image offers several advantages over low-resolution images for forest cover mapping, e.g. the ability to map smaller patches. On the other hand, the season of image acquisition has impact on the detectability of vegetation. One potential issue with the aerial photographs acquired in December-January in the 1990s could be snow cover that could affect the interpretation of forest cover especially in the High Mountains and the High Himal physiographic regions, while the issue with March-April image used in the 2010s assessment could be the defoliation of some deciduous tree species that makes forest cover mapping challenging.

Method of forest mapping is probably the most important issue when we want to look for changes. The results of the two assessments are not directly comparable due to the differences between the pixel-based and the object-based image analysis. Further, point sampling using aerial photographs potentially offers quick and cost effective method for area calculation, but the accuracy depends on appropriate sample design. On other hand, the hybrid approach used in the recent assessment has been recommended as simple, robust and costeffective (GOFC-GOLD, 2008). The compilation of results from different sources in the 1990s NFI posed yet another challenge to compare results against a uniform approach applied in the recent FRA (Table 1). Consistency in data collection and analysis may be an important issue in assessment involving compilation from different sources. A Minimum Mapping Unit (MMU) is defined as "the smallest size areal entity to be mapped as a discrete entity" (Lillesand et al., 2014). As the MMU determines the extent of detail in the map (Saura, 2002), it is one of the most critical issues in comparing the two assessments. The FRA had a much smaller MMU than the NFI. The higher mapping resolution (or lower MMU) generally results in increased forest area as compared to the lower mapping resolution since small patches that are not visible on lower-resolution images can be mapped on higher-resolution ones. This could be one of the reasons why the estimate of forest area was more in the latest assessment.

Despite the difficulty in direct comparison with previous assessment, the latest assessment did establish a baseline for a range of forest resource assessment parameters.

Table 1: Comparison of forest assessments in the 1990s and 2010s

\begin{tabular}{|c|c|c|c|}
\hline & NFI 1990's & FRA 2010's & Description \\
\hline \multicolumn{4}{|l|}{ Materials } \\
\hline $\begin{array}{l}\text { Base data for } \\
\text { forest area } \\
\text { mapping and } \\
\text { interpretation }\end{array}$ & $\begin{array}{l}\text { Combination of aerial photos and } \\
\text { satellite image (Landsat TM); Aerial } \\
\text { photo covered } 83.7 \% \text { of Nepal's area } \\
\text { while satellite image covered } 16.3 \%\end{array}$ & $\begin{array}{l}\text { Wall-to-wall coverage } \\
\text { of Rapideye images }\end{array}$ & $\begin{array}{l}\text { The differences in data sets } \\
\text { used to map forest cover } \\
\text { makes comparison difficult. }\end{array}$ \\
\hline Scale & $\begin{array}{l}\text { Aerial photo at 1:50000 scale and } \\
\text { remaining area covered by Landsat } \\
\text { TM Satellite Image of } 30 \mathrm{~m} \text { spatial } \\
\text { resolution }\end{array}$ & $5 \mathrm{~m}$ spatial resolution & $\begin{array}{l}\text { The resolution determines } \\
\text { the ability to map smaller } \\
\text { patches. }\end{array}$ \\
\hline $\begin{array}{l}\text { Data } \\
\text { acquisition } \\
\text { month }\end{array}$ & December-January & March-April & $\begin{array}{l}\text { Season of image acquisition } \\
\text { affects the detectability of } \\
\text { vegetation. }\end{array}$ \\
\hline \multicolumn{4}{|l|}{ Methods } \\
\hline $\begin{array}{l}\text { Forest area } \\
\text { estimation }\end{array}$ & $\begin{array}{l}\text { Point sampling using aerial photos } \\
\text { and visual interpretation of grid } \\
\text { system for } 51 \text { districts. }\end{array}$ & $\begin{array}{l}\text { Wall-to-wall mapping } \\
\text { through integration of } \\
\text { advanced object-based }\end{array}$ & $\begin{array}{l}\text { The methods used for forest } \\
\text { area estimation are entirely } \\
\text { different. }\end{array}$ \\
\hline
\end{tabular}




\begin{tabular}{|c|c|c|c|}
\hline & & $\begin{array}{l}\text { image classification; } \\
\text { classification and } \\
\text { regression tree (CART) } \\
\text { and extensive visual } \\
\text { interpretation using } \\
\text { high-resolution Google } \\
\text { Earth Image. }\end{array}$ & \\
\hline Sources of data & $\begin{array}{l}\text { Compilation of work done by different } \\
\text { organizations (Satellite image analysis: } \\
\text { NFI- } 16.3 \% \text { of area, District Forest } \\
\text { Inventory- } 8.5 \% \text { of area, Churia } \\
\text { forest inventory- } 3.1 \% \text { of area and the } \\
\text { remaining } 51 \text { Hill Districts- } 72.1 \% \text { of } \\
\text { area) }\end{array}$ & FRA Nepal single work & $\begin{array}{l}\text { Consistency in data } \\
\text { collection and analysis would } \\
\text { pose an important issue in } \\
\text { comparison. }\end{array}$ \\
\hline $\begin{array}{l}\text { Minimum } \\
\text { mapping unit } \\
\text { (MMU) }\end{array}$ & $\begin{array}{l}\text { Varied based on methods used, ranging } \\
\text { from } 1 \text { to } 25 \text { ha. Satellite Image } \\
\text { Analysis: }>9 \text { ha (assumed } 10 \text { pixels); } \\
\text { District Forest Inventory: } 6.25 \text { ha and } \\
25 \text { ha as } 1: 25000 \text { and } 1: 50000 \text { scale } \\
\text { aerial photos were used; Churia Forest } \\
\text { Inventory: } 6.25 \text { ha; Remaining Hill } \\
\text { Districts: } 1 \text { ha. }\end{array}$ & $0.5 \mathrm{ha}$ & $\begin{array}{l}\text { Marked differences in MMU } \\
\text { will have implications on } \\
\text { the mapping output, leading } \\
\text { to difficulty in comparison } \\
\text { between the assessments. }\end{array}$ \\
\hline \multicolumn{4}{|l|}{ Duration } \\
\hline $\begin{array}{l}\text { Assessment } \\
\text { period }\end{array}$ & 1987-1998 (12 years) & 2011-2014 (4 years) & $\begin{array}{l}\text { Changes might have occurred } \\
\text { due to the long duration of } \\
\text { assessment in the case of } \\
\text { NFI. }\end{array}$ \\
\hline \multicolumn{4}{|l|}{ Verification } \\
\hline $\begin{array}{l}\text { Field } \\
\text { verification }\end{array}$ & Not done & $\begin{array}{l}\text { The mapping results } \\
\text { were validated against } \\
\text { field data for Terai, } \\
\text { Churia, Middle } \\
\text { Mountains; for High } \\
\text { Mountains and High } \\
\text { Himal, verification } \\
\text { done by using high } \\
\text { resolution images in } \\
\text { Google earth. }\end{array}$ & $\begin{array}{l}\text { Field verification is important } \\
\text { to assure validity and } \\
\text { reliability of any mapping } \\
\text { work; it was lacking in } \\
\text { NFI (1994), was conducted } \\
\text { Field verification in } 3 \\
\text { physiographic regions in } \\
\text { FRA (2010-2014). }\end{array}$ \\
\hline $\begin{array}{l}\text { Accuracy } \\
\text { assessment }\end{array}$ & $\begin{array}{l}\text { Done for hilly area }(72.09 \% \text { of total } \\
\text { area with } 7,685 \text { grids; the forest and } \\
\text { shrub area combined estimate being } \\
37.7 \% \text { with a } 95 \% \text { confidence limit of } \\
1.1 \% \text {; thus, in terms of percentage, the } \\
\text { area can vary from } 36.6 \% \text { to } 38.8 \% \text {. }\end{array}$ & $\begin{array}{l}\text { The forest cover } \\
\text { mapping accuracy was } \\
\text { evaluated in terms } \\
\text { of overall accuracy } \\
(85.16 \%) \text { and kappa } \\
(0.72 \text { with standard } \\
\text { error of } 0.0175) \text {. This } \\
\text { assessment, however, } \\
\text { doesn't provide } \\
\text { confidence limits of } \\
\text { area estimates. }\end{array}$ & $\begin{array}{l}\text { The confidence limit of } \\
\text { forest statistics could not be } \\
\text { determined due to wall-to- } \\
\text { wall mapping in the FRA } \\
(2010-2014) \text {. }\end{array}$ \\
\hline $\begin{array}{l}\text { Verification } \\
\text { with } \\
\text { independent } \\
\text { approach }\end{array}$ & $\begin{array}{l}\text { Not done; the results reported from the } \\
\text { point sampling only. }\end{array}$ & $\begin{array}{l}\text { The results were also } \\
\text { obtained by using } \\
\text { independent method } \\
\text { through visual interpre- } \\
\text { tation of regular grids } \\
\text { of points }(>55,358) \text { at } 4 \\
\text { km interval throughout } \\
\text { the country. }\end{array}$ & $\begin{array}{l}\text { The estimates from the } \\
\text { latest assessment seem } \\
\text { reliable as the mapping } \\
\text { was verified with extensive } \\
\text { visual interpretation and field } \\
\text { verification (DFRS, 2015). }\end{array}$ \\
\hline
\end{tabular}


Subsequent future assessments will produce information on forest cover change. However, to measure changes and track the impact of forestry sector policy and programme interventions, it is necessary to compare forest cover with consistent methods and datasets in at least smaller areas, if not possible for the whole country.

\section{References}

Crowther, T. W., Glick, H. B., Covey, K. R., Bettigole, C., Maynard, D. S., Thomas, S. M., Smith, J.R., Hintler, G., Duguid, M. C., Amatulli, G. and Tuanmu, M. N. 2015. Mapping tree density at a global scale. Nature 525 (7568): 201-205.

DFRS. 1999. Forest Resources of Nepal (19871998). Department of Forest Research and Survey (DFRS), Kathmandu, Nepal.

DFRS. 2015. State of Nepal's Forests. Forest Resource Assessment (FRA) Nepal, Department of Forest Research and Survey (DFRS), Kathmandu, Nepal.
FRS. 1967. Forest Statistics for the Terai and Adjoining Regions. Publication No. 4. Forest Resources Survey (FRS), Kathmandu, Nepal.

GOFC-GOLD. 2008. Reducing greenhouse gas emissions from deforestation and degradation in developing countries: a sourcebook of methods and procedures for monitoring, measuring and reporting, GOFC-GOLD Report version COP132. Global Observation for Forest Cover and Land Dynamics Project Office, Natural Resources Canada, Alberta, Canada.

Lillesand, T., Kiefer, R. W. and Chipman, J. 2014. Remote Sensing and Image Interpretation. John Wiley and Sons, New York, USA.

Saura, S. 2002. Effects of minimum mapping unit on land cover data spatial configuration and composition. International Journal of Remote Sensing 23 (22): 4853-4880. 